\title{
鋼木質複合構造システムに適合 IN-PLAIN SHEAR TEST OF JOINT OF するCLT 床接合部の面内せん CLT FLOOR ADAPTING CSTS SYSTEM 断実験
}

\author{
藤田正則 — $* 1$ 大瀧麻世 $-* 2$ \\ 大越友樹 — $* 3$ 菊池剛和 — $* 4$ \\ 小谷野一尚— $* 5$ 岩田 衛—— \\ キーワード : \\ 鋼木複合構造, スタッド，ボルト， CLT 床，面内せん断実験， \\ 降伏せん断耐力
}

Keywords:

Composite steel-timber structure, Stud, Bolt, Cross laminated timber floor, In-plane shear test, Yield shear strength

\begin{tabular}{|c|}
\hline $\begin{array}{l}\text { Masanori FUJITA } \\
\text { Yuki OKOSHI- } \\
\text { Kazuhisa KOYANO }\end{array}$ \\
\hline
\end{tabular}

Mayo OTAKI $-* 2$
Takamasa KIKUCHI- $* 4$
Mamoru IWATA $-* 6$

In light of the global environment, the authors proposed a building system comprising steel and timber (Hereafter referred to as CSTS), which consist of rolled section steels and timbers. A design method of the CSTS uses the concept of a damage controlled structure and its mechanical model is established based on the previous tests. In this study, we propose floor structure adapting for the CSTS using cross laminated timber. In-plane shear test of the joint which are consisted of unheaded studs or bolts for joint of the CSTS beam and floor structure is conducted. Structural performances of joint of the CSTS beam and floor structure are evaluated. The findings obtained from tests indicate that the joint of the CSTS beam and the floor structure has a high stiffness and strength.

\section{1. 序論}

環境負荷削減のための対応として建築構造分野では，木質材料を 可能な限り多く使用することで森林再生に貢献しようとする試みが 模索されている1 ${ }^{15}$ )。その一つとして鋼木質複合構造の研究が進め られている ${ }^{6 \sim 10)}$ 。著者らも, 主に非住宅分野の中低層建物に木質材 料を有効活用するため，機能性と安全性を損なうことのない，鋼木 質複合構造システム(以降, この構法をComposite stee1-timber structureからCSTSという) を開発している ${ }^{11) \sim 13) 。 こ こ て ゙ は, ~ C S T S ~}$ に適合する床構法を提案することで，木質材料の利用部位の拡大を 目指すものである。

中低層建物の床には，耐火性や遮音性などからデッキプレートに コンクリートを打設することが一般的である。これに対して，耐火 性等の課題はあるものの，大スパンが可能で軽量化が可能な直交集 成板 (以降, Cross laminated timber から, CLTという)等が開発さ

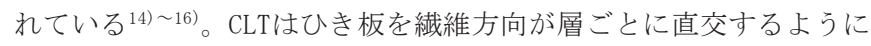
重䄈て接着した大判のパネルで, 床や耐震壁として利用した研究が 報告されている ${ }^{17) \sim 20) 。 ~}$

本報告では，CSTSに適合する床構法として，CSTS梁とCLT床の接 合にスタッドあるいはボルトを用いた接合部の基本的な力学的性状 を面内せん断実験により検討する。

\section{CSTSに適合する床構造}

\section{1 CSTSの概要}

鋼木質複合構造システム (CSTS) は, 制振部材として座屈拘束ブレ 一スを方杖状に配置した損傷制御構造としている21)。これにより， 柱梁接合部や部材継手を含む部位は, 剛接合ではなく, 半剛接合と することで座屈拘束ブレースのエネルギー吸収効率を向上させ，主 架構の損傷を抑えることができる。すなわち, 大地震に遭遇しても

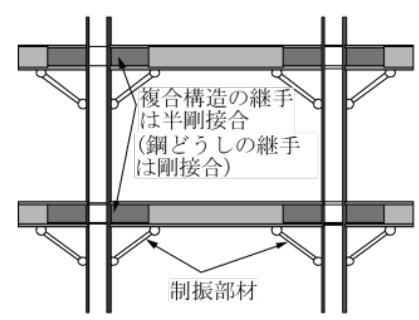

(a) 架構

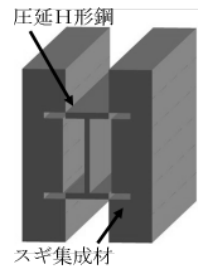

(b) 梁部材

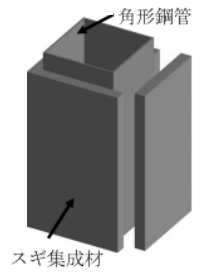

(c) 柱部材

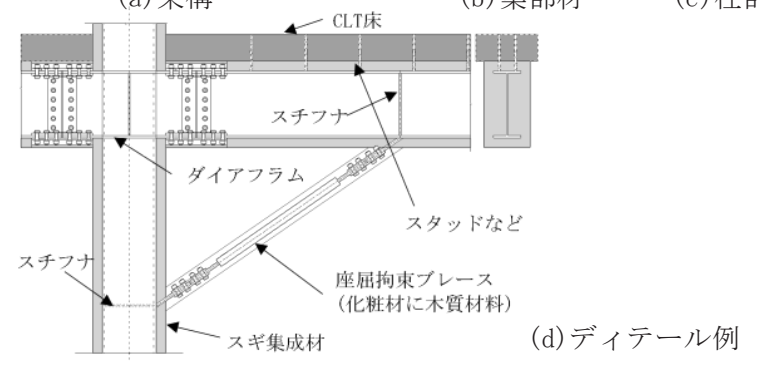

図 1 鋼木質複合構造システム（CSTS）

\footnotetext{
山口大学大学院創成科学研究科 教授・博士 (工学

（７55-8611 山口県宇部市常盤台 2 丁目 16-1)

山口大学大学院創成科学研究科 大学院生

ナイス㑣) 修士（工学）

神奈川大学大学院工学研究科 大学院生

神奈川大学工学部建築学科 助手・修士 (工学)

${ }^{6}$ 神奈川大学工学部建築学科 教授・工博
}

\footnotetext{
Prof., Graduate School of Sciences and Technology for Innovation, Yamaguchi Univ., Dr. Eng.

2 Graduate Student, Graduate School of Sciences and Technology for Innovation, Yamaguchi Univ.

3 Nice Corporation, M. Eng.

${ }^{*} 4$ Graduate Student, Dept. of Architecture and Building Eng., Kanagawa Univ.

*5 Research Assoc., Dept. of Architecture and Building Eng., Kanagawa Univ., M. Eng.

6 Prof., Dept. of Architecture and Building Eng., Kanagawa Univ., Dr. Eng.
} 
座屈拘束ブレースで地震エネルギーを吸収するために，柱梁への損 傷を抑えることができる。また，損傷した座屈拘束ブレースのみを 交換，修復して建物の持続性を図ることができる ${ }^{22)}$ 。CSTS部材は, 鋼の周囲に木質材料を取り付けた複合部材で構成される10)（図 1 ）。 鋼は部材リユースを想定し, 事務所や工場・倉庫に多く使用されて いる圧延H形鋼を梁に, 角形鋼管を柱に用いることを想定している。 CSTSは，鋼材の周囲をスギ集成材で覆うもので，鋼と木質材料を接 触接合としているため，鋼と木質材料の施工・解体が容易になる。

\section{2 CSTS梁と床の接合法}

ここで, CSTS 梁に適合する床に, 軽量化と大スパンを可能とした CLT を用いてみる。この接合法は, CLT 床と鋼材の周囲をスギ集成材 で覆うCSTS 梁をスタッドまたはボルトで接合することを特徵とし ている。CSTS 梁はスタッドまたはボルトなどの接合具を介して CLT 床と緊結する。CSTS 梁の集成材およびCLT 床にはあらかじめスタッ ドまたはボルト用の孔を座彫しておく。スタッド接合の場合, 接着 剤を充填することで，CSTS 梁と床材を一体化する。なお，接着剤は 耐火性や耐久性の課題があるものの，ここでは取り上げない。CSTS 梁と CLT 床がボルト接合の場合, 解体・分離が容易であり，床の上 下階の部分的な増改築にも対応でき, 建築計画上の自由度が高いと いえる。

\section{3. 面内せん断実験}

\section{1 試験体の選定}

試験体は大きく 3 つのシリーズに分けており，シリーズ 1 におい てスタッド長さ, シリーズ 2 においてスタッドの間隔, シリーズ 3 においてCLTの厚さ(ボルト接合)をパラメータとする23)。面内せん断 実験に用いる試験体一覧, 試験体の形状を表 1 , 図 2 に各々示す。 スタッド接合の試験体は, スタッド長さL $(100 \mathrm{~mm}, 130 \mathrm{~mm}, 160 \mathrm{~mm})$ を共 通とし,シリーズ 1 においてスタッド間隔 $100 \mathrm{~mm}$ ，シリーズ 2 におい てスタッド間隔 $200 \mathrm{~mm}$ とした各 3 種類の試験体(計12体)である。ボル 卜接合の試験体 (シリーズ 3 ) は, CLT厚さT (90mm, 150mm, 210mm)
の 3 種類の試験体 (計 6 体) とする。

シリーズ 1,2 において, スタッドは 1 列配置(スタッド本数 : 4 本), シリーズ 3 において, ボルトは 2 列配置 (ボルトの間隔は 200 $\mathrm{mm}$ ，ボルト本数：8 本) とする。CSTS梁に用いる鋼材はSS400材の圧 延H形鋼 (H-200x200x8x12) とする。スタッドあるいはボルトには丸 鋼（ $\phi 12 ：$ SS400) を使用する。スタッドは頭無しスタッドとし，圧延 H形鋼のフランジ面両側に各々配置し，予め溶接する。ボルトは丸 鋼端部のねじ部を加工する。鋼材を覆うスギ集成材は被り厚さ $50 \mathrm{~mm}$ とし，ウェブ面およびフランジ面それぞれに対応して 4 分割し，フ ランジ面をスタッドやボルトで接合する(図 3 )。スタッドあるいは ボルトと接合する木質材料には，接合用の孔(径 $16 \mathrm{~mm}$ )を設ける。ス

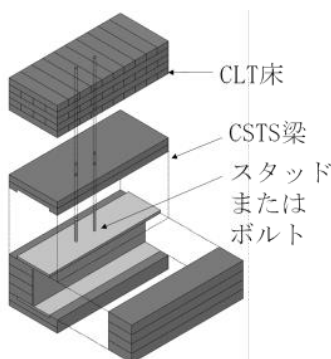

図 3 CSTS 梁と CLT 床 の接合の模式図

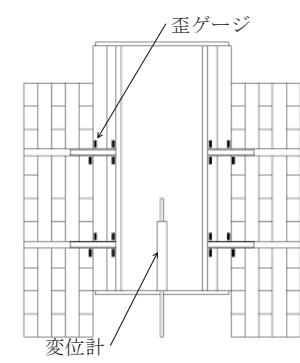

図 5 測定箇所
表 2 材料の機械的性質

\begin{tabular}{|c|c|c|c|c|c|c|c|}
\hline シリーズ & 材料 & 材質 & $\begin{array}{l}\text { 圧縮 } \\
\text { 強度 }{ }^{* 1} \\
\mathrm{~N} / \mathrm{mm}^{2}\end{array}$ & \begin{tabular}{|l} 
支圧 \\
強度 \\
$\mathrm{N} / \mathrm{mm}^{2}$
\end{tabular} & $\begin{array}{l}\text { 降伏 } \\
\text { 強度 } \\
\mathrm{N} / \mathrm{mm}^{2}\end{array}$ & \begin{tabular}{|l} 
引張 \\
強さ \\
$\mathrm{N} / \mathrm{mm}^{2}$
\end{tabular} & $\begin{array}{c}\text { 伸び } \\
\%\end{array}$ \\
\hline \multirow{2}{*}{$\begin{array}{l}\text { シリーズ } 1 \\
\text { シリーズ } 2\end{array}$} & 集成材 & E65-F225 & 43 & 47 & -- & -- & -- \\
\hline & CLT & $\begin{array}{l}\text { Mx60-3層 } 3 \\
\text { プライ }\end{array}$ & 14 & 20 & -- & -- & -- \\
\hline \multirow[b]{2}{*}{ シリーズ 3} & 集成材 & E65-F225 & 44 & 47 & -- & -- & -- \\
\hline & CLT & $\begin{array}{l}\text { Mx60-3層 } 3 \\
\text { プライ }\end{array}$ & 12 & 18 & -- & -- & -- \\
\hline $\begin{array}{l}\text { シリーズ } 1 \\
\sim 3\end{array}$ & $\begin{array}{l}\text { スタッド, } \\
\text { ボルト }\end{array}$ & SS 400 & -- & -- & 339 & 450 & 33 \\
\hline
\end{tabular}

注*1 集成材 (繊維方向), CLT (3 層 3 プライで繊維と直角方向）

注*2 支圧強度は, 製造ロットの異なる試験片の支圧強度と圧縮 強度の比率より求めた。

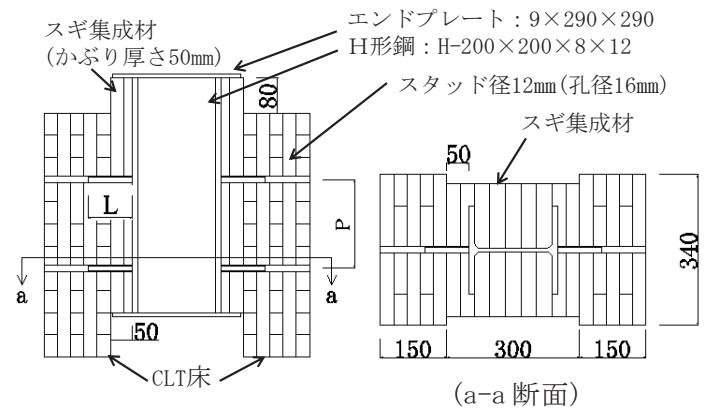

(a) シリーズ 1 , シリーズ 2

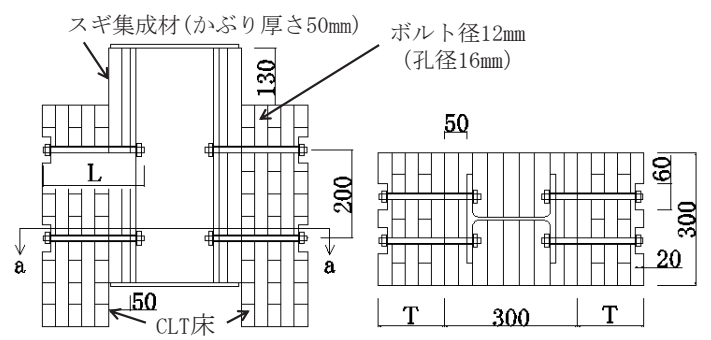

(b) シリーズ 3

図 2 試験体形状図

\begin{tabular}{|c|c|c|c|c|c|c|c|c|c|}
\hline \multirow[b]{2}{*}{ シリーズ*1 } & \multirow[b]{2}{*}{ 試験体名 } & \multicolumn{4}{|c|}{ スタッド・ボルト } & \multirow{2}{*}{$\begin{array}{c}\text { CLT床の } \\
\begin{array}{c}\text { 厚さ (T) } \\
\text { mm }\end{array} \\
\end{array}$} & \multirow{2}{*}{$\begin{array}{l}\text { 試験 } \\
\text { 体数 }\end{array}$} & \multicolumn{2}{|c|}{ 含水率 } \\
\hline & & 配列 & $\begin{array}{c}\text { 間隔 (P) } \\
\text { mm }\end{array}$ & $\begin{array}{c}\text { 長さ (L) } \\
\mathrm{mm}\end{array}$ & 本数 & & & $\begin{array}{c}\text { 集成材 } \\
\%\end{array}$ & $\begin{array}{c}\text { CLT } \\
\%\end{array}$ \\
\hline \multirow{3}{*}{$\begin{array}{l}\text { シリーズ } 1 \\
\text { (スタッド) }\end{array}$} & \begin{tabular}{|l|l} 
L100P100 \\
\end{tabular} & 1 & 100 & 100 & 4 & \multirow{6}{*}{150} & 2 & 13.5 & 12.4 \\
\hline & L130P100 & 1 & 100 & 130 & 4 & & 2 & 13.5 & 12.6 \\
\hline & \begin{tabular}{|l|}
$\mathrm{L} 160 \mathrm{P} 100$ \\
\end{tabular} & 1 & 100 & 160 & 4 & & 2 & 12.8 & 13.0 \\
\hline \multirow{3}{*}{$\begin{array}{l}\text { シリーズ } 2 \\
\text { (スタッド) }\end{array}$} & L100P200 & 1 & 200 & 100 & 4 & & 2 & 13.0 & 10.6 \\
\hline & L130P200 & 1 & 200 & 130 & 4 & & 2 & 13.4 & 11.9 \\
\hline & \begin{tabular}{|l|}
$\mathrm{L} 160 \mathrm{P} 200$ \\
\end{tabular} & 1 & 200 & 160 & 4 & & 2 & \begin{tabular}{|l|}
13.1 \\
\end{tabular} & 13.2 \\
\hline \multirow{3}{*}{$\begin{array}{l}\text { シリーズ } 3 \\
\text { (ボルト) }\end{array}$} & L170T90 & 2 & 200 & 170 & 8 & 90 & 2 & 9.7 & 9.0 \\
\hline & \begin{tabular}{|l|} 
L230T150 \\
\end{tabular} & 2 & 200 & 230 & 8 & 150 & 2 & 9.3 & 8.9 \\
\hline & \begin{tabular}{|l|} 
L290T210 \\
\end{tabular} & 2 & 200 & 290 & 8 & 210 & 2 & 9.5 & 10.1 \\
\hline
\end{tabular}

注*1 CSTS 梁の木質材料(集成材)の被覆厚さ: $50 \mathrm{~mm}$

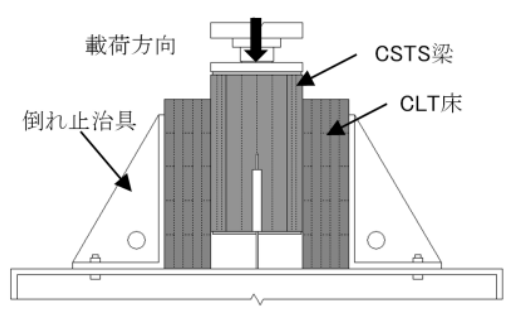

（a）載荷装置の模式図

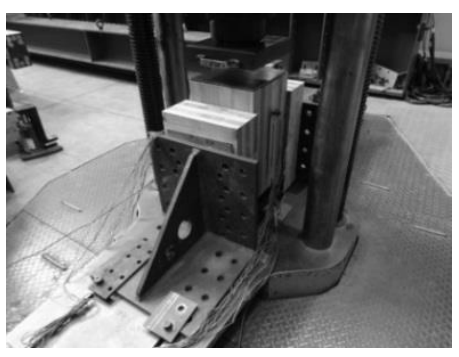

（b）載荷状況
図 4 載荷装置 
タッド接合の試験体においてはスタッドの施工後, エポキシ樹脂系 接着剂を充填する。

CSTS梁には，スギ集成材(異等級構成：E65-F225)を使用し，床材 には，スギCLT(異等級構成Mx60：3層3プライ・5層5プライ・7層7プ ライ)を使用する。CLT床の厚さはシリーズ 1,2 において $150 \mathrm{~mm}$ ，シ リーズ 3 において $90 \mathrm{~mm}, 150 \mathrm{~mm}, 210 \mathrm{~mm}$ である。載荷の際に均一な面 で加力を行うために圧延 $H$ 形鋼の端部にエンドプレートを設ける。 試験体の載荷方向は, CSTS梁のスギ集成材において繊維方向, CLT 床において弱軸方向とする。材料の機械的性質を表 2 に示す。各試 験体の機械的性質は, 各シリーズの材料に対して 3 体の平均である。 集成材には, 試験片 (䋊維方向: 100mmx100mmx200mm), CLTには, 試験 片 (3層3プライで繊維と直角方向: $90 \mathrm{~mm} \times 90 \mathrm{mmx} 180 \mathrm{~mm}$ ) を使用する。

\section{2 載荷・計測方法}

面内せん断実験にあたっては万能試験機を用いる。載荷中に試験 体の構面外の倒れを防ぐために両側に治具を設置する (図 4)。加力 は一方向単調載荷とする。試験は最大荷重に達した後, 最大荷重の $70 \%$ まは変位が約 $80 \mathrm{~mm}$ 程度 (試験体が試験装置に干渉しない限界) に達するまで載荷する。計測は, 図 5 に示すように各試験体に取り

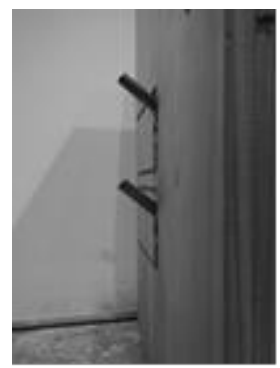

(a) L100P100

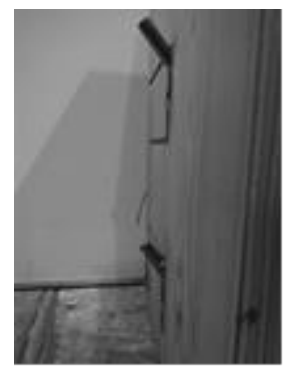

(b) L100P200
(CSTS 梁側)

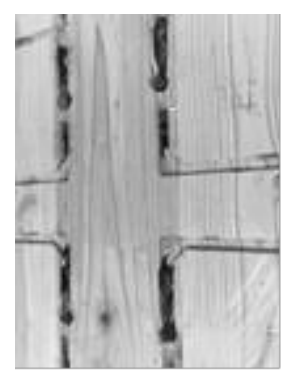

(a) L230T150

(CSTS 梁側)

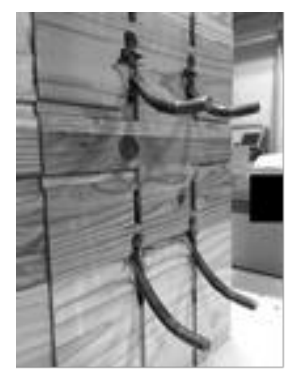

(b) L230T150

(CLT 床側)

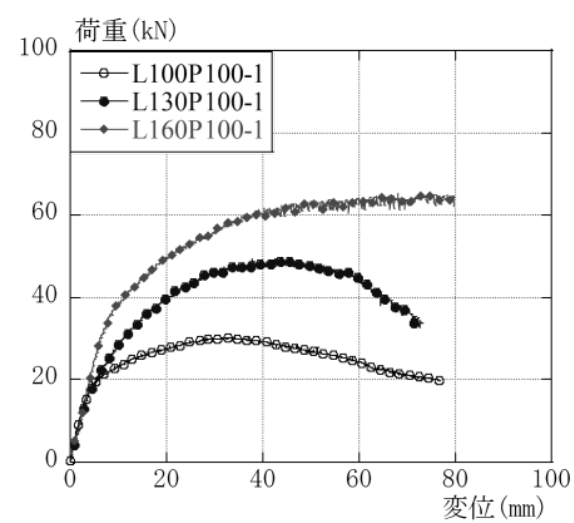

(a) シリーズ 1

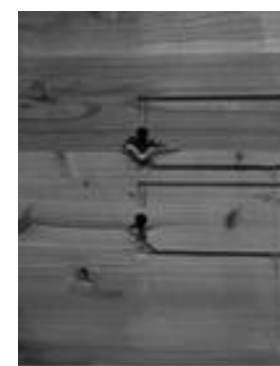

(c) L100P100
付けた変位計及び歪ゲージ (CSTS梁, CLT床，スタッドあるいはボル トの脚部近傍に貼付)によって行う。

\section{3 実験結果}

1 ) 破壊性状

シリーズ $1 ， 2$ およびシリーズ 3 の試験体の破壊性状を図 6 , 図 7 に各々示寸。各試験体の破壊性状は主にスタッドあるいはボルト の曲げ変形とそれらと木質材料の接触部分での支圧破壊である。全 ての試験体において，試験体中央のCSTS梁材が載荷方向に沈み込む ように変形したものの, CSTS梁とCLT床の木質材料には割裂破壊やせ ん断破壊は生じていない。

スタッドを用いた試験体 (シリーズ 1，2）では，スタッド長さに よる変形性状の差異が見られた。L100P100，L130P100のスタッドは 主にCSTS梁側の集成材の内部で大きく曲がっていたが，L160P100に おいてはCSTS梁材の内部とCLT床で大きな曲げ変形が確認された。こ れらの破壊形式は後述する破壊モードIII b, IV に各々該当する。スタ ッドによる木質材料の支圧破壊の位置は, CSTS梁においてスタッド の直上部, CLT床においてスタッドの直下部である。一方, スタッド の間隔の異なるシリーズ 1 とシリーズ 2 において同じスタッド長さ

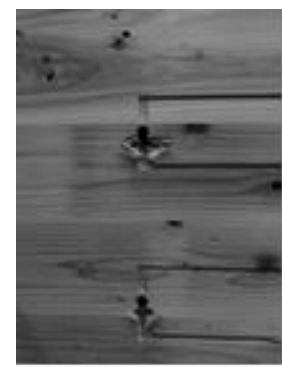

(d) L100P200
(CLT 床側)

図 6 破壊状況(シリーズ 1 , シリーズ 2 )

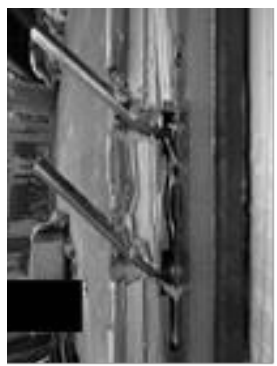

(e) L130P100

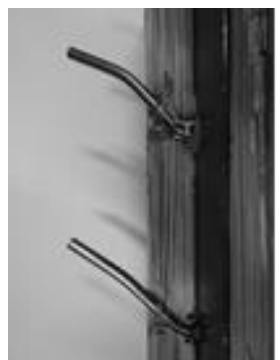

(f) L160P200
(CSTS 梁)

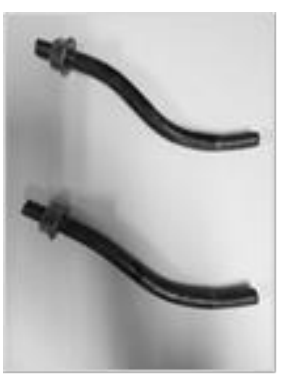

(c) L230T150

(ボルト)

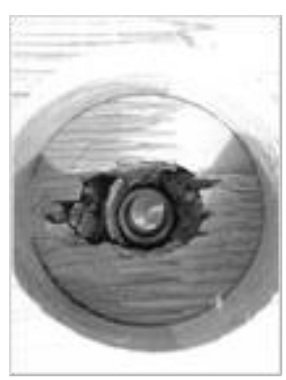

(d) L230T 150 (座金近傍)

図 7 破壊状況(シリーズ 3 )

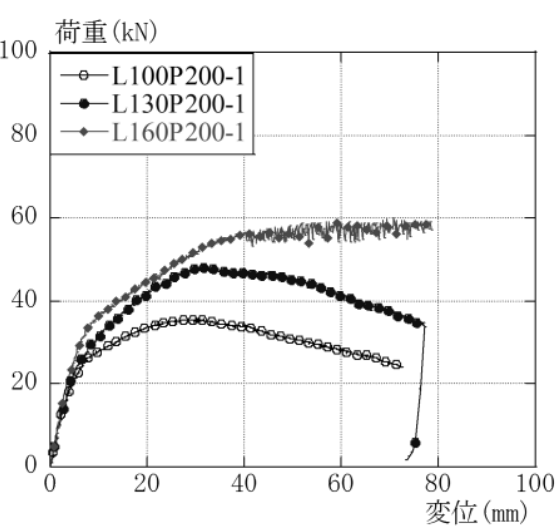

(b) シリーズ 2

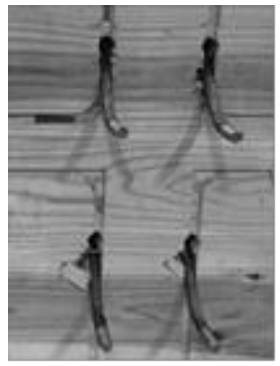

(e) L170T90

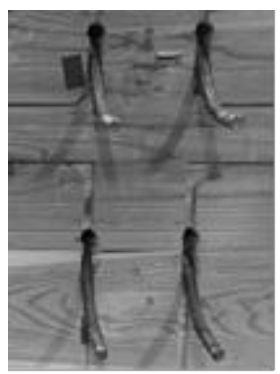

(f) L290T210
(CLT 床側)

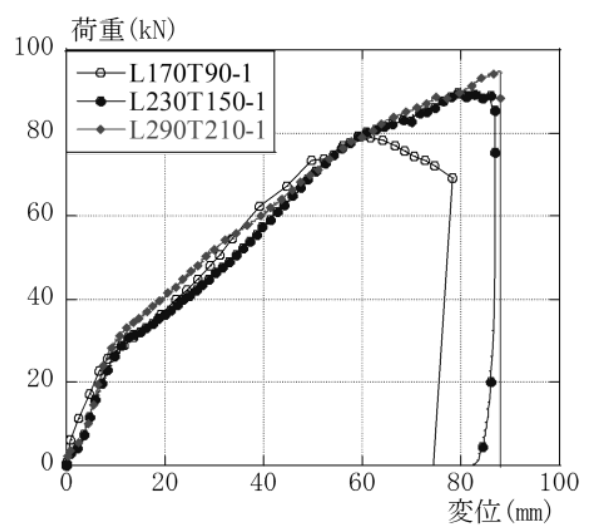

(c) シリーズ 3

図 8 荷重変位曲線 
のもとでの破壞性状の差異は見られなかった。

ボルトを用いた試験体(シリーズ３)では，全ての試験体において CSTS梁の集成材の内部とCLT床でボルトの曲げ変形が確認された。 CSTS梁とCLT床と接触面のボルトによる木質材料の支圧破壊がシリ ーズ 1 とシリーズ 2 と同様に生じている。これらの破壊形式は後述 する破壊モードIVに該当する。さらに，ボルトの座金裏面がCLT側 へめり込んでいた。

ボルトによる木質材料の支圧破壊の位置は，シリーズ 1,2 と同 様にCSTS梁の集成材においてボルトの直上部, CLT床においてボルト の直下部である。

\section{2) 接合部耐力}

シリーズ $1 ， 2$ およびシリーズ 3 の試験体の実験結果一覧表，各 シリーズの代表的な荷重変位曲線を表 3 , 図 8 に各々示す。各試験 体の接合部の降伏せん断耐力は, 接合部の標準試験法 ${ }^{24)}$, 25) によって いるが，最大荷重が得られなかった試験体においては，荷重変位曲 線の第一折れ点を採用している。ただし, シリーズ 3 はシリーズ 1 , 2 と比較のため, ボルト 4 本あたりの荷重である。接合具 (スタッド あるいはボルト)の降伏時の荷重は $0.2 \%$ オフセット法によって算定 している。

シリーズ 1,2 の降伏せん断耐力は，スタッドの降伏時の荷重の

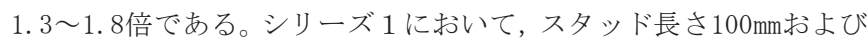
$130 \mathrm{~mm}$ 試験体は最大荷重に到達以降, 荷重の低下が見られるが, ス

表 3 実験結果一覧表

\begin{tabular}{|c|c|c|c|c|c|c|c|c|}
\hline \multirow{3}{*}{ シリーズ } & \multirow{3}{*}{ 試験体名 } & \multirow{2}{*}{\multicolumn{2}{|c|}{ 接合具 }} & \multicolumn{4}{|c|}{ CSTS梁とCLTの接合部 } & \multirow{3}{*}{$\begin{array}{l}\text { 接合具 } \\
\text { の降伏 } \\
\text { 時の荷 } \\
\text { 重*2 }\end{array}$} \\
\hline & & & & \multirow{2}{*}{$\begin{array}{l}\text { 初期 } \\
\text { 剛性 } \\
\mathrm{kN} / \mathrm{mm}\end{array}$} & \multirow{2}{*}{\begin{tabular}{|c} 
降伏せん \\
断耐力 \\
$\mathrm{kN}$
\end{tabular}} & \multirow{2}{*}{$\begin{array}{c}\text { 最大 } \\
\text { 荷重 } \\
\mathrm{kN}\end{array}$} & \multirow{2}{*}{$\begin{array}{c}\text { 終局 } \\
\text { 耐力 } \\
\mathrm{kN}\end{array}$} & \\
\hline & & $\begin{array}{c}\text { 間隔 } \\
\mathrm{mm}\end{array}$ & $\begin{array}{c}\text { 長さ } \\
\text { mm }\end{array}$ & & & & & \\
\hline \multirow{6}{*}{$\begin{array}{l}\text { シリーズ } 1 \\
\text { (スタッド) }\end{array}$} & L100P100-1 & \multirow{6}{*}{100} & \multirow[b]{2}{*}{100} & 3.3 & 19.1 & 30.2 & 27.5 & -- \\
\hline & L100P100-2 & & & 4.5 & 20.2 & 31.9 & 29.5 & 15.5 \\
\hline & \begin{tabular}{|l} 
L130P100-1 \\
\end{tabular} & & \multirow[b]{2}{*}{130} & 2.5 & 25.9 & 49.3 & 44.8 & -- \\
\hline & L130P100-2 & & & 4.7 & 26.7 & 53.5 & 48.1 & 18.3 \\
\hline & \begin{tabular}{|l|} 
L160P100-1 \\
\end{tabular} & & & 4.3 & 35.3 & 65.0 & 58.7 & -- \\
\hline & $\mathrm{L} 160 \mathrm{P}$ & & 160 & 4.8 & 31.9 & 55.0 & 51.3 & 17.8 \\
\hline \multirow{6}{*}{$\begin{array}{l}\text { シリーズ } 2 \\
\text { (スタッド) }\end{array}$} & L100 & \multirow{6}{*}{200} & \multirow{2}{*}{100} & 3.5 & 21.6 & 35.5 & 32.3 & -- \\
\hline & L100P & & & 3.3 & 20.4 & 31.5 & 28.8 & 17.2 \\
\hline & L130P200-1 & & \multirow[b]{2}{*}{130} & 4.6 & 25.5 & 48.2 & 43.1 & -- \\
\hline & L130P200-2 & & & 4.7 & 25.8 & 49.6 & 45.5 & 20.5 \\
\hline & L160P200-1 & & \multirow[b]{2}{*}{160} & 3.7 & 31.6 & 59.7 & 53.2 & -- \\
\hline & L160H & & & 4.4 & 30.7 & 53.5 & 50.0 & 18.0 \\
\hline \multirow{6}{*}{$\begin{array}{l}\text { シリーズ } 3^{* 1} \\
\text { (ボルト) }\end{array}$} & L170T90-1 & \multirow{6}{*}{200} & \multirow[b]{2}{*}{170} & 2.9 & 24.1 & 79.1 & 60.4 & -- \\
\hline & L170T90-2 & & & 2.6 & 31.1 & 76.7 & 58.6 & 26.1 \\
\hline & L230T 150-1 & & \multirow[b]{2}{*}{230} & 2.8 & 29.0 & -- & -- & -- \\
\hline & L230T150-2 & & & 2.8 & 35.0 & -- & -- & 32.2 \\
\hline & \begin{tabular}{|l} 
L290T210-1 \\
\end{tabular} & & \multirow[b]{2}{*}{290} & 3.4 & 34.7 & $\overline{--}$ & $\overline{--}$ & -- \\
\hline & L290T210-2 & & & 4.0 & 28.9 & $\overline{--}$ & $\overline{--}$ & 34.2 \\
\hline
\end{tabular}

注*1 各耐力はボルト 4 本あたりに換算している。

*2 スタッドまたはボルトの $0.2 \%$ 時の荷重(歪ゲージ)

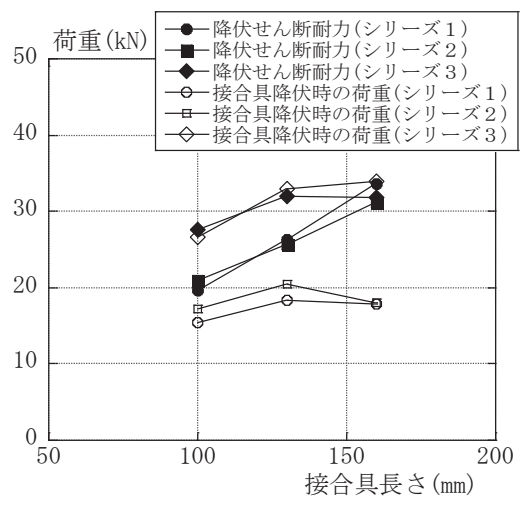

図 9 降伏せん断耐力と接合具長さ

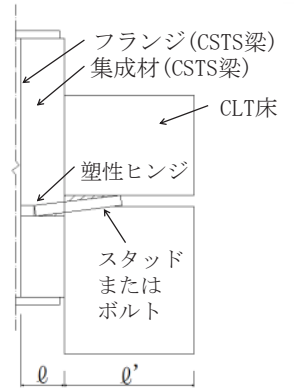

III $b$ 降伏モード
タッド長さ $160 \mathrm{~mm} の$ 試験体は最大荷重後も荷重が低下せず変位が進 む結果となった。また，スタッド間隔の異なるシリーズ 1 とシリー ズ 2 において, 同じスタッド長さの場合, スタッド間隔の違いによ る降伏せん断耐力や終局耐力の差異は見られなかった。

シリーズ 3 のボルト接合とした試験体では，降伏後に最大荷重に 到達したものはL170T90のみで, 他の試験体に関しては耐力の向上が 見られた。荷重変位曲線においては，シリーズ 1 とシリーズ 2 と異 なり，第一折れ点が明確に見られた。また，CSTS梁とCLT床の接合部 の初期剛性はCLT床の厚さに伴い僅かに上昇する傾向となった。

\section{4. 考察}

\section{1 降伏せん断耐力と接合具長さ}

シリーズ 1 とシリーズ 2 のCSTS梁とCLT床の接合部の降伏せん断 耐力および接合具（スタッド，ボルト）の降伏時の荷重と接合具長 さの関係を図 9 に示す。ここで, 接合具長さはスタッドあるいはボ ルトの長さ, 降伏せん断耐力は試験体 2 体の平均である。接合部の 降伏せん断耐力は接合具長さが大きい程，増大する傾向にある。ま た，接合具の降伏時の荷重は接合具長さにかかわらず，変動は少な い。これらの傾向は接合具の間隔の異なるシリーズ 1 とシリーズ 2 において概ね同様の傾向を示す。

シリーズ 3 の接合部の降伏せん断耐力は, 接合具の降伏時の荷重 と概ね同じ程度になっている。これは, ボルト接合の試験体において は,スタッド接合に比べ，ボルトの頭部および座金裏面の抵抗が生 じたためと考えられる。

\section{2 ヨーロッパ型降伏理論による降伏せん断耐力}

CSTS梁とCLT床の接合部の降伏せん断耐力をヨーロッパ型降伏理 論 $(\mathrm{EYT})$ 24) 27)により検討してみる。これは曲げ降伏型接合具を用い た接合部の降伏せん断耐力を推定したもので，複数の降伏モードを 用いてもたらすせん断力の最小值をその接合部の降伏せん断耐力と している。このうち, CSTS梁とCLT床の接合部の一面せん断実験によ る降伏モードを図10に示す。接合形式と降伏モードによって定める 係数Cは接合具 (スタッド, ボルト) がCSTS梁側で降伏するモードIII b，あるいはCSTS梁側とCLT側の両方が降伏するIVに該当する。CSTS 梁とCLT床の接合部の降伏せん断耐力は (1) 式を用いる。

$$
{ }_{c} P_{y}=C \cdot F_{e} \cdot d \cdot \ell
$$

ここで, ${ }_{c} P_{y}:$ 接合部の降伏せん断耐力 $(\mathrm{N})$

$F_{e}, F_{e}{ }^{\prime}$ : 主材 (CSTS梁), 側材 (CLT床) の基準支圧強度 $\left(\mathrm{N} / \mathrm{mm}^{2}\right)$ $F$ : 接合具の基準材料強度 $\left(\mathrm{N} / \mathrm{mm}^{2}\right)$

表 4 接合部の降伏せん断耐力の比較

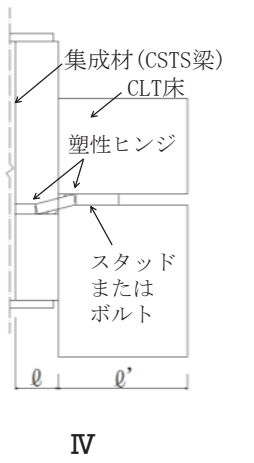

図 10 面内せん断実験による

\begin{tabular}{|c|c|c|c|c|c|}
\hline \multirow[t]{2}{*}{ シリーズ } & \multirow[t]{2}{*}{$\begin{array}{l}\text { 接合具 } \\
\text { の長さ }\end{array}$} & \multicolumn{2}{|c|}{\begin{tabular}{|l} 
接合部の降伏 \\
せん断耐力
\end{tabular}} & \multirow[t]{2}{*}{${ }_{e} P_{y} /{ }_{c} P_{y}$} & \multirow[t]{2}{*}{$\begin{array}{l}\text { 破壊 } \\
\text { 形式*2 }\end{array}$} \\
\hline & & \begin{tabular}{|c|} 
実験值 \\
${ }_{e} P_{y}^{* 1}$ \\
$(\mathrm{kN})$
\end{tabular} & $\begin{array}{c}\text { 算定值 } \\
{ }_{c} P_{y} \\
(\mathrm{kN})\end{array}$ & & \\
\hline \multirow{3}{*}{ シリーズ 1} & 100 & 19.7 & 26.3 & 0.7 & III b \\
\hline & 130 & 26.3 & 34.1 & 0.8 & III b \\
\hline & 160 & 33.6 & 32.4 & 1.0 & IV \\
\hline \multirow{3}{*}{ シリーズ 2} & 100 & 21.0 & 26.3 & 0.8 & III $b$ \\
\hline & 130 & 25.7 & 34.1 & 0.8 & III b \\
\hline & 160 & 31.2 & 32.4 & 1.0 & IV \\
\hline \multirow{3}{*}{ シリーズ 3} & 100 & 27.6 & 31.3 & 0.9 & IV \\
\hline & 130 & 32.0 & 31.3 & 1.0 & IV \\
\hline & 160 & 31.8 & 31.3 & 1.0 & IV \\
\hline
\end{tabular}
*2 ヨーロッパ型降伏理論による降伏モード
注*1 降伏せん断耐力は 2 体の平均值を示す。 


$$
\begin{aligned}
& C: \text { 接合形式と降伏モードによって定める係数 } \\
& d: \text { 接合具径 }(\mathrm{mm}), \quad \ell, \ell^{\prime}: \text { 主材厚 }(\mathrm{mm}), \text { 側材厚 }(\mathrm{mm}) \\
& \alpha=\frac{\ell \prime}{\ell} ， \quad \beta=\frac{F_{e}^{\prime}}{F_{e}}, \quad \gamma=\frac{F}{F_{e}} \\
& \text { 降伏モードIII b }: \mathrm{c}=\sqrt{\frac{2 \alpha^{2} \beta^{2}(1+\beta)}{(2 \beta+1)^{2}}+\frac{2 \beta \gamma\left(\frac{d}{l}\right)^{2}}{3(2 \beta+1)}}-\frac{\alpha \beta}{2 \beta+1} \\
& \text { 降伏モードIV }: \quad \mathrm{c}=\frac{d}{l} \sqrt{\frac{2 \beta \gamma}{3(1+\beta)}}
\end{aligned}
$$

CSTS梁とCLT床の接合部の降伏せん断耐力の実験值と算定值の比 較を表 4 に示す。ここで, 各シリーズの試験体において, 主材厚 $(\ell=50 \mathrm{~mm})$, 側材厚 $\left(\ell^{\prime}=70 \mathrm{~mm}, 130 \mathrm{~mm}, 190 \mathrm{~mm}\right)$ は, 接合具がCSTS梁の木 質材料, CLT床と接触している部分を有効長さとする。木質材料の基 準支圧強度は, 製造ロットの異なる試験片の圧縮強度と支圧強度の 比より求めた。なお，ここでは，スタッドまたはボルトに生じる塑 性ヒンジの位置に着目してヨーロッパ型降伏理論の算定式を用いた が，スタッドまたはボルトの長さや境界条件の相違が接合部の降伏 せん断耐力に与える影響の検討は今後の課題とする。

シリーズ 1 , シリーズ 2 の場合, 接合具長さ $100 \mathrm{~mm}, 130 \mathrm{~mm}$ の試験 体 (L100P100, L160P100, L100P200, L160P200) は降伏モードIIIb, ス タッド長さ160mmの試験体 (L160P100, L160P200) は降伏モードIVに該 当する。シリーズ 3 の場合, 全て降伏モードIVに該当する。CSTS梁 とCLT床の接合部の降伏せん断耐力の実験值は破壊モードIVにおい て, 算定值と概水一致するものの, 破壊モードIIIbにおいて, 低めの 評価となる。

\section{5. 結論}

本報告では, CSTS 梁とスタッドあるいはボルトで接合された CLT 床の面内せん断実験を行った結果，下記のことが明らかになった。

1) CSTS 梁と CLT 床の接合部は, スタッドあるいはボルトの曲げ降 伏に伴い, CSTS 梁とCLT 床の木質材料の接触部や座金裏面の支 圧破壊である。

2 ) CSTS 梁と CLT 床の接合部の耐力は, スタッド間隔が $100 \mathrm{~mm}$ と $200 \mathrm{~mm}$ の場合，概ね同じである。

3 ) CSTS 梁と CLT 床の接合部の降伏せん断耐力は, スタッド接合の 場合，接合具長さが長くなるに連れて増加する。

4) CSTS 梁と CLT 床の接合部の降伏せん断耐力の実験值は破壊モー ドIVにおいて，算定值と概ね一致するものの，破壊モードIII bに おいて, 低めの評価となる。

\section{謝辞}

本研究は, 平成 $27 \sim 29$ 年度の文部科学省科学研究費補助金 (基盤 研究 (C) )の助成を受けました。本研究にあたり, 神奈川大学工学部 学生 (当時) 小太刀常滋氏, 片瀬浩彰氏の協力を得ました。記して深 く感謝致します。

\section{参考文献}

1)木質材料復興：日経アーキテクチュア, pp. 28-37, 2010.4

2) 日本建築学会地球環境委員会 : 地球環境時代における木材の活用推進のシ ナリオ, 2011 年度日本建築学会大会 (関東), 地球環境部門研究協議会資料, 2011.8

3)一般社団法人 木を活か寸建築推進協議会 : 木造建築の寸寸め, 2009.11
4) 日経 BP 社 : 既存の技術を組み合わせて木の構造を見せる, 日経アーキテ クチュア, pp. 58-63, 2008.9

5) 建築技術: 金沢エムビル（特集新しい木造耐火建築物の潮流と可能性 最新 の木造耐火建築物の事例) 建築技術, pp. 152-155, 2005.7

6) 長村寛行, 桐野康則, 腰原幹雄：5階建木質複合構造建築の実現に関する 研究 その 1 建物概要・防火計画, 日本建築学会大会学術講演梗概集, C-1, 構造III, pp. 199-200，2005.9

7) 桐野康則, 長村寛行, 腰原幹雄 : 5 階建木質複合構造建築の実現に関する 研究 その 2 構造概要, 日本建築学会大会学術講演梗概集, $C-1$, 構造III, pp. 201-202, 2005. 9

8) 腰原幹雄, 五十田博, 長村寛行, 桐野康則 : 5 階建木質複合構造建築の実 現に関する研究 その 3 構造要素の性能, 日本建築学会大会学術講演梗概 集, C-1, 構造III, pp. 203-204, 2005.9

9) 堀井健史, 坂田弘安, 竹内徹, 鈴木達人, 中村博志 : シアリング接合を用 いた杉集成材と鋼板によるハイブリッド部材の力学的挙動に関する実験研 究, 日本建築学会構造系論文集, 第 584 号, pp. 125-132, 2004. 10

10) 小林研治, 安村基, 成田敏基, 李元羽: 単板積層材の直交層が接合部の支 圧強度及び割裂破壊定数に及ぼす影響, 日本建築学会大会学術講演梗概, 集，C-1，構造III，pp. 119-120，2015.9

11) 藤田正則, 宿輪桃花, 大越友樹, 村井正敏, 岩田衛 : 鋼と木質材料の複合 構造システムの構法成立の可能性, 日本建築学会環境系論文集, 第 78 巻, 第 691 号, pp. 725-731，2013.9

12) 大越友樹, 藤田正則, 村井正敏, 岩田衛: 鋼木質複合梁部材の曲げ実験, 日本建築学会技術報告集, 第 19 巻, 第 43 号, pp. 967-970, 2013. 10

13) 藤田正則, 大越友樹, 村井正敏, 岩田衛 : 鋼と木質材料の複合構造に関す る研究 その 1 接触接合梁の曲げ実験, 日本建築学会大会学術講演梗概 集，C-1，構造III，pp. 929-930，2013.8

14) 武川明子 : 第 1 部 情報集 : CLT の最前線 3. 欧州における CLT の普及と使 用例，木材工業，68(11), pp. 474-475, 2013

15) 直交集成板の日本農林規格, 平成 25 年 12 月 20 日, 農林水産省告示大 3079 号

16）国土交通省：CLT を用いた木造建築基準の高度化推進事業報告書, 平成 26 年度

17) 倉富洋, 森宗二郎, 工藤僚恭, 山形毬乃, 上川大輔, 矢垰和彦, 藤井秀行, 稲田達夫 : 柱梁 S 造一床木質構造システムの開発 その 1 開発の趣旨 について, 日本建築学会大会学術講演梗概集, 構造III, pp. 515-516, 2015.9

18) 森宗二郎, 倉富洋, 藤井秀行, 稲田達夫 : 柱梁 S 造一床木質構造システ ムの開発 その 2 鉄骨梁と木床の接合方法, 日本建築学会大会学術講演 梗概集， C-1，構造III，pp. 517-518，2015.9

19) 山形毢乃, 倉富洋, 稲田達夫 : 柱梁 S 造一床木質構造システムの開発 そ の 4 施工性確認実験, 日本建築学会大会学術講演梗概集, C- 1 , 構造III, pp. 521-522, 2015. 9

20) 弥浦壮太, 五十田博, 槌本敬大, 中川貴文, 北守顕久, 鈴木圭, 津田千 尋 : 小幅パネルを引きボルト接合したCLT 壁の水平力に対する挙動, 日本 建築学会構造系論文集, vol. 81, 第 721 号, pp. 585-593, 2016.3

21) Mamoru IWATA, Masanori FUJITA : A Damage-Controlled Structure Using Buckling-Restrained Knee Braces, Structural Engineering

International, Vol.21, No. 3, pp. 462-470, 2011. 11

22) 大越友樹, 藤田正則, 小田大貴, 岩田 衛: 座屈拘束方杖ブレースを有す る鋼木質複合構造の設計法の提案, 日本建築学会構造系論文集, 第 79 巻, 第 700 号, pp. 847-855, 2014.6

23) 大瀧麻世, 藤田正則, 小谷野一尚, 岩田 衛: CSTS 梁とスタッドで接合さ れた CLT 床の一面せん断実験, 日本建築学会大会学術講演梗概集, C-1, 構造III, pp. 1075-1076, 2016.8

24) 日本建築学会編: 木質構造設計基準 - 同解説 -許容応力度 $\cdot$ 許容耐力設計 法-, 2011.3

25) 日本住宅・木材技術センター:構造用木材の強度試験マニュアル，2011.3

26) 日本建築学会 : 木質構造基礎理論, 2010.12

27) 日本建築学会 : 木質構造接合部設計マニュアル, 2012.4

[2017 年 6 月 5 日原稿受理 2017 年 8 月 15 日採用決定 $]$ 